\title{
Országspecifikus oktatási terminusok terminológiai és szociolingvisztikai elemzése a Termini magyar-magyar szótár példái alapján (Ausztria)
}

\section{Bevezetés}

A magyarok számára Ausztria a nyugati irányú elvándorlás és ingázás egyik legközelebbi és legkedveltebb célországa volt évszázadokon keresztül, és így van ez napjainkban is. Az ideérkezők motivációja is sokféle: korábban politikai, ideológiai céllal mentek vagy menekültek ide az emberek, napjainkban leggyakrabban gazdasági, de ezen túl oktatási és egyéb személyes oka is van a migrációnak. A kivándorló magyar népcsoport motiváció, társadalmi összetétel, nyelvtudás és képzettségi fok tekintetében is vegyes.

A legfrissebb adatok szerint 2021 elején 91396 magyar állampolgár élt Ausztriában. A Magyarországgal szomszédos országokból érkező bevándorlók száma a statisztika szerint a következőképpen alakul: a román állampolgárok száma 131788 , a szerbeké 122 116, a horvátoké 89 002, a szlovákoké $45378^{1}$ fó, és ezen belül a magyar nemzetiségü személyekről nincs pontos adatunk.

A magyar népcsoport oktatásának törvényi szabályozása nem változott, noha őshonos népcsoportként a burgenlandi (1976), valamint a Bécsben és környékén élő magyar népcsoportot is elfogadták (1992), ám a bécsi magyaroknak azóta sincs iskolatörvényük. Az itt élő magyar gyerekek magyaroktatása a civil szervezetek délutáni órakínálata szerint történik, csekély kivételtől eltekintve. A magyarok számának folyamatos emelkedésével nő a magyaroktatás iránti igény is, ${ }^{2}$ ugyanakkor ennek nincs meg a burgenlandihoz hasonló törvényi és intézményes kerete sem. A kiérkező családok vagy egymáshoz, vagy a civil szervezetekhez fordulhatnak segítségért, egyéb tanácsadó intézmény nincs a császárvárosban.

2019-ben részt vettem a Nemzetstratégiai Kutatóintézet Az oktatási struktúrák Kárpát-medencei makroregionális együttmüködését támogató kutatások címü projektjében, amelynek keretében többek között a Kárpát-medencében élő magyarság szociális hátránykezelésének feltárása volt a cél, ezen belül az oktatási és nyelvi hátrányhoz vezető problémáké. A kutatás során derült fény több olyan - a kivándorló családok körében felmerülö - oktatással, kétnyelvüséggel kapcsolatos problémára, ami veszélyeztetheti az emigráns családok gyermekeinek sikeres iskolai előmenetelét. Írásomban ezt a problémát mutatom be interdiszciplináris megközelítésben a Termini magyar-magyar szótár terminusainak illusztris példáin keresztül. A tanulmány célja problémafelvetés csupán, amelyet későbbi kutatásokkal lehetne mélyebben feltárni.

Írásomban ausztriai német oktatási terminusokat elemzek, és a kiválasztott tíz terminuson keresztül próbálok rámutatni azokra az oktatási rendszerbeli különbsé-

1 https://de.statista.com/statistik/daten/studie/293019/umfrage/auslaender-in-oesterreichnach-staatsangehoerigkeit/ (Utolsó nézet: 2021.08.12.)

2 Az AMAPED 2003-as megalakuláskor csak egy helyszínen oktatott. A honlap tájékoztatása szerint 2021-ben nyolc helyszínen tanítanak. https:/amaped.at/ (Utolsó nézet: 2021.08.12.) 
gekkel összefüggő nehézségekre, amelyekkel az Ausztriában élő és gyermeket nevelő allochton magyar népcsoport tagjainak szembe kell néznie.

A problémák gyökere szerteágazó: a két ország oktatási rendszerének Monarchia utáni különfejlődése ugyanúgy befolyásoló tényezö, mint a szülők képzettsége, társadalmi tagozódása, az államnyelvi kompetenciájuk különböző foka, a kapcsolati hálójuk hiánya stb. (Nem vizsgálom az oktatási rendszerek közötti átjárhatóságot és a határmenti tanulási célú ingázás jelenlegi helyzetét.) A kiválasztott tíz terminus segítségével arra szeretnék csupán rámutatni, hogy az oktatási rendszerek különfejlődése a kivándorló gyermekek esetében oktatási és nyelvi hátrányhoz vezethet a következő esetekben:

- ha a szülő nem ismeri az osztrák iskolarendszert,

- a kiköltözés elött nem tájékozódott alaposan,

- nem megfelelő az államnyelvi kompetenciája, így nem tudja képviselni gyermeke érdekeit az oktatási intézményekben.

A terminusok részletes elemzésével - amelyben a szociolingvisztika és a terminológia módszertanát egyaránt alkalmazom - azt is szeretném igazolni, (1) hogy a tükörfordításuk nem jelent feltétlenül segítséget a megértésükben, (2) és hogy megértésük hiánya a sikeres iskolai előmenetelt akadályozza. A probléma elemzéséhez röviden bemutatom az Ausztriában élő magyar diaszpórát, a Termini magyar-magyar szótárt és az alkalmazott módszertant.

\section{Nyelvpolitika: terminológiapolitika, oktatáspolitika}

A nyelvröl való tudatos gondolkodás a nyelvet beszélő közösségnek és a nyelv jövőjének is záloga (vö. pl. Tolcsvai Nagy 2017: 20). Különösen fontos ez napjainkban, amikor a 21. századi globalizálódás mögött a társadalom és a gazdaság átrendeződése zajlik, amelyben robbanásszerüen felgyorsult a tőke, az információ, az áru, az értékek és az eszmék áramlása (Szoták 2017a: 72), és ebben a kontextusban egyre többször kell beszélnünk a nyelvek versenyképességéröl, nyelv és gazdaság viszonyáról. A versenyképesség kritériuma a nyelvről való tudatos gondolkodás, és ezt a cselekvési tervet egy explicit nyelvstratégiai dokumentumnak kellene magába foglalnia. E stratégiai dokumentum része lehetne a napjainkban szintén aktuális terminológiastratégia (lásd Fóris-Bölcskei szerk. 2019). Azt, hogy miért érezzük a nyelvstratégia és ezen belül a terminológiastratégia hiányát, elegendő azzal magyaráznunk, hogy a nemzeti szókincs majdnem 90\%-át a szakszavak és a szakkifejezések adják (Karcsay 1978: 515). A magyar mint pluricentrikus nyelv jövöje, versenyképessége jelen írásnak nem tárgya, de a címben megjelölt témával nagyon is összefügg.

A magyar nyelv egyszerre nyolc országban fejlődik a Kárpát-medencében. A Termini Magyar Nyelvi Kutatóhálózat határtalanító programjában (Benő-Péntek szerk. 2011) ismertetett elképzelés szerint a magyar nyelv szétfejlődésének folyamata 1920 után kezdődött, majd a rendszerváltozás után a szétfejlödést újra a közeledés váltotta fel, és a tudománypolitikában nemcsak a terminisek által alkotott határtalanitás terminus jelent meg, hanem még több közeledésre utaló kifejezés: 
egységes Kárpát-medencei oktatási tér, egyetemes magyar nyelv, kulturális egység, a magyar nemzet egysége stb.

Az oktatáspolitikában ez a folyamat a következőképpen zajlott: a környező országokban élő magyar népcsoportok iskolahálózata 1920 után a többségi iskolarendszerbe integrálódott, így a környező hét országban a többségivel együtt, de az anyaországitól különfejlődött, más-más rendszerelemeket, eltérő módszertant és szemléletmódot hordoz. Az iskolarendszerek felépítése között látszólag sok a hasonlóság, de most a különbségeken, a specifikus, lokális eltéréseken van a fö hangsúly.

Írásomban olyan nyelvi problémákról írok, amelyek leírása és értelmezése az alkalmazott nyelvészet több területét is érinti, például oktatás, kétnyelvűség, szociolingvisztika, nyelvpolitika és terminológia. A nyelvpolitika részét képezi az oktatáspolitika és a terminológiapolitika is. Míg az elöbbiben az oktatásra vonatkozó cselekvés részeként az anyanyelvhez való jog kisebbségi léthelyzetben meghatározó, addig ez utóbbi az anyanyelv használatának fontos részeként tekint a szaknyelv- és terminológiahasználatra (Tamás 2019: 18). Több diszciplína területét érintve természetesen dolgozatom fontos háttereként hazánk és Ausztria nyelv- és oktatáspolitikájának, valamint oktatási rendszerének ismeretére támaszkodom.

\section{A Termini magyar-magyar szótár, a határtalanítás és az adatbázis oktatási szaknyelvi terminusai}

A határtalanítás, pontosabban a szóhatártalanítás a 2000-es évektől a Termini Magyar Nyelvi Kutatóhálózat legfontosabb kutatási programja, amely egyszerre jelent lexikológiai, lexikográfiai és korpusznyelvészeti feladatokat és nem utolsó sorban a mai élő nyelv egységes, a Kárpát-medence minden régiójára kiterjedő dokumentálását. Maga a határtalanítás folyamata napjainkban sem zárult le, csak újabb jelentéstartalommal bővült, és megjelent a társadalomtudományok egyéb területein is, továbbá a magyar nyelvtudomány egyik kiemelkedő feladatává vált (vö. Tolcsvai 2013: 379; Szoták 2017b: 229).

A határtalanítás folyamatához kötődik a közel húsz éve gyarapodó Termini magyar-magyar szótár építése. A napjainkban több mint ötezer szócikket tartalmazó online adatbázis a hét külső régió nyelvváltozatainak lexémáit tartalmazza, olyan kölcsönszavakat, amelyek a kisebbségi létből fakadóan és az államnyelvi hatás következményeként részei az ott élő kétnyelvü beszélöközösségek nyelvi repertoárjának.

Az Osztrák-Magyar Monarchia felbomlása, majd a trianoni békediktátum után a környezö államok oktatási rendszerével párhuzamosan az oktatás szaknyelve is különfejlődött. Ez a történelmi változás már eleve strukturális és terminológiai böséget eredményezett, ugyanakkor a 20-21. századi folyamatos szakpolitikai reformok ezt a folyamatot tovább erősítették. A változás során új kifejezések, szakszavak, terminusok keletkeztek nemcsak hazánkban, hanem a környező országokban is. A Termini magyar-magyar szótárból az eddig leírtakkal összefüggésben tehát célzottan olyan lexémákat, országspecifikus oktatási terminusokat dolgoztam ki a terminológia módszertana szerint (Tamás 2019), amelyek a célkitüzésemet igazolják, ugyanakkor rámutatnak a szótár sokszínűsége, hasznosíthatóságára is. 


\section{Az Ausztriában élő magyar diaszpóra}

A bécsi magyarok története egészen a középkorig vezethető vissza, és ez részben a bécsi és a magyar városok polgárai és arisztokrata családjai közötti családi kötelékeknek köszönhető, részben a Bécsben tanuló diákok népes seregének, valamint az udvarban dolgozott hivatalnokoknak. Az azóta eltelt évszázadok alatt a vándorlás okai nem sokat változtak (politikai, oktatási, személyes, gazdasági), csak koronként más-más motivációja volt az emigrációnak. Napjainkban egyértelmüen a gazdasági okok határozzák meg a vándorlás intenzitását.

Sajnos a Kárpát-medence országaiból Ausztriába érkező magyarok számáról pontos adatunk nincs, mert a cenzus állampolgárság szerint tartja nyilván a bevándorlókat. A hivatalosan népcsoportként is elismert, Bécsben és környékén letelepedett migráns eredetü, osztrák állampolgársággal rendelkező magyar diaszpóra létszáma 15435 föt tett ki a 2001-es cenzus adatai szerint, azóta frissebb adatok a regiszteralapú népszámlálás miatt nem állnak rendelkezésünkre, de becslések szerint több százezer magyar él Ausztriában.

A 2021 júniusában az általam végzett online szociolingvisztikai kutatás alapján ${ }^{3}$ és a civil szervezetek vezetőivel készített korábbi interjúk tartalmára alapozva kijelenthetjük, hogy az újonnan érkező migrációs csoport összetétele kor, végzettség és nyelvtudás szempontjából is vegyes. Az interjúk szerint sokszor előfordul, hogy a szülők segítséget kérnek a civil szervezetek munkatársaitól oktatási kérdésekben. Ezeken a találkozókon derült ki, hogy azokban a családokban, amelyekben a szülő nyelvi kompetenciája alacsony, a szülő nem tudja ellátni érdekérvényesítő szerepét: nincs a megfelelő információ birtokában, nem tudja feltenni a kérdéseit, nem jutnak el hozzá olyan információk az iskolából, amelyek fontosak lennének az iskolai előmenetel szempontjából. ${ }^{4}$ Különösen igaz ez akkor, ha a gyermek sem beszéli a nyelvet, és ennek a nyugati szomszédunknál megvan a törvényes lehetősége: a tanulót akkor is fel lehet venni, ha nem rendelkezik megfelelő szintủ nyelvtudással, de legfeljebb egyéves időtartamra. Ez alatt a tanuló elsajátíthatja a nyelvet a szükséges szinten. ${ }^{5}$

A fentebb leírt hiányok esetében a civil szervezetek oktatási szakemberei, pedagógusai azt tanácsolják a szülőknek, hogy költözzenek vissza Magyarországra annak érdekében, hogy elkerüljék az iskolai kudarcot. Egyik reprezentatív példa erre a szituációra a Schularbeit terminus (lásd később), amely írásbeli dolgozatot jelent, leginkább a magyarországi témazáró dolgozathoz hasonlítható, ám sokkal nagyobb súlya van az iskolákban. Az elemi iskola negyedik osztályában különösen fontos például a német és matematika tantárgyakból megírt dolgozat eredménye a gimnázi-

3 Az ausztriai magyar diaszpóra körében végezetem online kérdőíves szociolingvisztikai tárgyú kutatást 2021. június 1-31. között. Az adatok feldolgozása folyamatban van.

4 Langerné (2017) nem számol be hasonló tapasztalatokról. Ennek oka a határ mentén kettős: egyrészt sokszor a magyarországi gyerekek léte menti meg az iskolát a bezárástól, másrészt a határmenti, burgenlandi iskolákban sok a magyarországi, magyarul tudó pedagógus.

5 Gesetzliche Grundlagen schulischer Maßnahmen für SchülerInnen mit anderen Erstsprachen als Deutsch. Forrás: http://www.schule-mehrsprachig.at/fileadmin/schule_mehrsprachig/ redaktion/Hintergrundinfo/info1-14-15.pdf (Utolsó nézet: 2021. 5.13.) 
umi felvételi szempontjából. Ha ennek tényével és súlyával a szülő nincs tisztában például nem tudja támogatni a gyermekét a felkészülésben, azt sem tudja, hogy nem hagyható ki -, akkor az általános iskola felső tagozatán tudja csak folytatni a tanulmányait (Mittelschule). Miért gond ez?

Az elemi iskolát követően a gyerekek egymás mellett párhuzamosan futó iskolatípusok közül választhatnak, amelyek tulajdonképpen már differenciálnak, meghatározzák a további életpályát, beindítva ezzel a kontraszelekciót a társadalomban. A Mittelschule után is mehetnek gimnáziumba a gyerekek, de az nehezebb út az egyetem felé. Sokszor előfordul tehát, hogy jó képességü, de németül még nem jól beszélő és értő magyar gyerekek egy osztályba járnak a sokkal gyengébben teljesítő osztrák gyerekekkel a Mittelschuléban. Arra is volt gyakorlat, hogy az iskola pedagógusa kimondta, hogy mivel nem osztrák állampolgár, így nem feltétlenül kell neki gimnáziumba (AHS) mennie. Legtöbbször azonban kimondatlanul próbálják ebbe az irányba terelni az iskolai folyamatokat. Ennek az az oka, hogy az érettséginek nagy súlya van az osztrák társadalomban.

A további terminusok azt példázzák (6-10), hogy Ausztriában a kötelező és szabadon választott tantárgyak tanulásának széles a palettája (Pflichtgegenstand $=$ kötelezö tantárgy, Wahlplichgegenstand = kötelezően választandó tantárgy, Verbindliche $\ddot{U b u n g}=$ kötelező gyakorlat, Unverbindliche Übung = szabadon választható gyakorlat, Freigegenstand = szabadon választható tantárgy), de egyáltalán nem könynyü kiismerni és megérteni a kínálatot, ezért is mutatom be az előbbi fogalmakat/ terminusokat és azok ekvivalenseit részletesen. A magyar nyelvet például minden felsorolt formában lehet tanulni a különbözö oktatási szinteken. Fontos azonban tudni, hogy érettségizni magyar mint idegen nyelvböl csak akkor lehet, ha négy éven keresztül jegykötelezettség mellett tanulta a diák a magyar nyelvet.

\section{A kidolgozott oktatási terminusok gyüjteménye}

Tanulmányom megírásakor korábbi szociolingvisztikai interjúk tapasztalataira, szakirodalmi ismereteimre, a terminusok elemzésekor pedig a terminológia mint modern diszciplína módszertanára támaszkodtam. ${ }^{6}$ Célom az volt, hogy a nyelvtudomány eredményeit és módszereit hasznosítsam, és hogy a Termini magyar-magyar szótárból kiválasztott - az oktatás témakörébe tartozó - példákon keresztül érintőlegesen bemutassam az oktatási terminológia jellegzetességeit és segítségükkel azokat a nyelvi problémákat, amelyek hátráltathatják a diákok sikeres iskolai előmenetelét.

A kidolgozott terminusok szinte mindegyike azért okozott nehézséget és ezáltal problémát, mert a fogalmi összehasonlítás folyamata, az ekvivalensek keresése a másik nyelven, azaz maga a megfeleltetés folyamata az oktatási rendszer és az oktatás szaknyelvének különfejlődése miatt nem volt egyszerü (Tamás 2019: 21). Arntz et al. (2009: 156, idézi Tamás 2019: 21) a fogalom más nyelvre való átültetésére három alapvető eljárást sorol fel: (1) szókölcsönzés és tükör-

6 Hálásan köszönöm a tanulmány során nyújtott szakmai segítségét Tamás Dóra Máriának és Sági Zsuzsannának. 
fordítás; (2) gondos nyelvtervezéssel a célnyelvnek megfelelő terminus alkotása; (3) parafrázis. Nos, a példákból az a következtetés vonható le, hogy a megfeleltetés komplex, nehéz feladat, törekedni kell a minél pontosabb és alaposabb fogalommeghatározásra.

A terminusok kidolgozása során a táblázatokat úgy állítottam össze, hogy abban a német terminus mellett szerepeljen a magyar nyelvü ekvivalens, definíció mindkét nyelven, illetve ahol szükségesnek találtam, ott részletesebben megmagyaráztam a fogalmat (vö. Tamás 2019) és annak oktatáspolitikai hátterét, mindezt gyakorlati példákkal illusztráltam, illetve megjelöltem a felhasznált internetes forrásokat, gyakran jogszabályokat is annak érdekében, hogy a jobb megértést szolgáljam.

\begin{tabular}{|c|c|c|}
\hline $\begin{array}{l}\text { 1. Terminus AT: } \\
\text { Volksschule (VS) }\end{array}$ & $\begin{array}{l}\text { Terminus HU: } \\
\text { általános iskola }\end{array}$ & $\begin{array}{c}\text { Ekvivalens: népiskola }(\mathrm{Au}) \\
\text { (tükörfordítás) }\end{array}$ \\
\hline $\begin{array}{l}\text { Definition: } \\
\text { „Die Volksschule umfasst } \\
\text { die Grundschule, bestehend } \\
\text { aus der Grundstufe I und } \\
\text { der Grundstufe II sowie bei } \\
\text { Bedarf die Oberstufe. Die } \\
\text { Grundstufe I umfasst bei } \\
\text { Bedarf die Vorschulstufe und } \\
\text { die 1. und 2. Schulstufe. Die } \\
\text { Grundstufe II umfasst die } 3 \text {. } \\
\text { und 4. Schulstufe., }\end{array}$ & $\begin{array}{l}\text { Definíció: Magyarországon } \\
\text { általános műveltséget } \\
\text { nyújtó, } 1-8 \text {. osztályig } \\
\text { terjedő közoktatási és } \\
\text { nevelési iskolatípus. }\end{array}$ & $\begin{array}{l}\text { Fogalmi összehasonlítás } \\
\text { eredménye / fogalmi } \\
\text { különbség leírása: } \\
\text { A két intézménytípus nem } \\
\text { feleltethető meg egymással. } \\
\text { Az osztrák népiskola olyan } \\
\text { önálló oktatási intézmény az } \\
\text { osztrák iskolarendszerben, } \\
\text { amely kizárólag az általános } \\
\text { iskola 1-4. osztályát jelöli. }\end{array}$ \\
\hline \multicolumn{3}{|c|}{ Az ekvivalencia szintje: részleges } \\
\hline \multicolumn{3}{|c|}{$\begin{array}{l}\text { Magyarázat: } \\
\text { A népiskola a német Volksschule tükörszavaként terjedt el, az 1868-as Népiskolai törvényre } \\
\text { vezethető vissza, amely alapján általánossá vált a tankötelezettség 6-12 éves kor között, } \\
\text { és létrejött a } 6 \text { osztályos népiskola. Hazánkban ez a kifejezés mára marginalizálódott. } \\
\text { Napjainkban Magyarországon az általános iskola első négy osztályának feleltethető meg. }\end{array}$} \\
\hline \multicolumn{3}{|c|}{$\begin{array}{l}\text { Források: } \\
\text { https://www.bmbwf.gv.at/Themen/schule/schulsystem/sa/vs.html } \\
\text { https://net.jogtar.hu/ }\end{array}$} \\
\hline
\end{tabular}




\begin{tabular}{|c|c|c|}
\hline $\begin{array}{c}\text { 2. Terminus AT: } \\
\text { Neue Mittelschule (NMS) / } \\
\text { Mittelschule (MS) }\end{array}$ & $\begin{array}{c}\text { Terminus HU: általános } \\
\text { iskola }\end{array}$ & $\begin{array}{c}\text { Ekvivalens: } \\
\text { új középiskola (tükörfordítás), } \\
\text { az általános iskola felső } \\
\text { tagozata }\end{array}$ \\
\hline $\begin{array}{l}\text { Definition: } \\
\text { Die Mittelschule (MS) } \\
\text { vermittelt SchülerInnen } \\
\text { von } 10 \text { bis } 14 \text { Jahren } \\
\text { eine grundlegende } \\
\text { Allgemeinbildung und } \\
\text { bereitet sie auf die } \\
\text { berufliche Erstausbildung } \\
\text { in einer Lehre oder } \\
\text { berufsbildenden mittleren } \\
\text { oder höheren Schule (BMS } \\
\text { oder BHS) oder eine höhere } \\
\text { Allgemeinbildung vor. }\end{array}$ & $\begin{array}{l}\text { Definíció: } \\
\text { Magyarországon általános } \\
\text { müveltséget nyújtó, } \\
1-8 . \text { osztályig terjedő } \\
\text { közoktatási és nevelési } \\
\text { iskolatípus. }\end{array}$ & $\begin{array}{l}\text { Fogalmi összehasonlítás } \\
\text { eredménye / fogalmi } \\
\text { különbség leírása: } \\
\text { A két intézménytípus nem } \\
\text { feleltethető meg egymással. } \\
\text { Magyarországon nincs } \\
\text { az osztrák fogalomnak } \\
\text { megfeleltethető magyar } \\
\text { fogalom. A középiskola nálunk } \\
\text { a } 8 \text { általános elvégzése után } \\
\text { következik. } \\
\text { A Mittelschule ugyanis olyan } \\
\text { önálló oktatási intézmény az } \\
\text { osztrák iskolarendszerben, } \\
\text { amely kizárólag az általános } \\
\text { iskola 5-8. osztályát jelöli (10- } \\
\text { től 14 éves korig járnak ide a } \\
\text { diákok), és felkészíti a tanulókat } \\
\text { arra, hogy szakiskolában, } \\
\text { szakközépiskolában vagy } \\
\text { gimnáziumban tanulhassanak } \\
\text { tovább. }\end{array}$ \\
\hline \multicolumn{3}{|c|}{ Az ekvivalencia szintje: részleges } \\
\hline \multicolumn{3}{|c|}{$\begin{array}{l}\text { Magyarázat: } \\
\text { Azt osztrák oktatási reformnak köszönhetően } 2008 \text { szeptemberétől* kísérleti modellként } \\
\text { vezették be a „,Die neue Mittelschule”programot, amely a 2015/2016-os tanévtől kötelező } \\
\text { érvényüvé vált, a Hauptschulékat váltotta ki. A 2019/20-as tanévig volt a neve Neue } \\
\text { Mittelschule. A Mittelschule a középfokú oktatás első szintjén foglal helyet az osztrák } \\
\text { iskolarendszerben (Sekundarstufe I.) }\end{array}$} \\
\hline \multicolumn{3}{|c|}{$\begin{array}{l}\text { Források: } \\
\text { https://www.ausbildungskompass.at/info/6-mittelschule/ } \\
\text { https://www.bildungssystem.at/fileadmin/user_upload/PDF/Neu_mit_BMB-Logo/ } \\
\text { Ungarisch_PlakatBS_2016_web.pdf }\end{array}$} \\
\hline
\end{tabular}

* 2008. január 9-én született törvény: Änderung des Schulorganisationsgesetzes BGBl. 26/2008; 242/1962. 


\begin{tabular}{|c|c|c|}
\hline $\begin{array}{c}\text { 3. Terminus AT: } \\
\text { Allgemeinbildende höhere } \\
\text { Schule (AHS) }\end{array}$ & $\begin{array}{c}\text { Terminus HU: } \\
8 \text { osztályos gimnázium }\end{array}$ & $\begin{array}{c}\text { Ekvivalens: Magas szintű } \\
\text { általános mủveltséget adó iskola } \\
\text { / } 8 \text { osztályos gimnázium }\end{array}$ \\
\hline $\begin{array}{l}\text { Definition: } \\
\text { „Die allgemein bildende } \\
\text { höhere Schule (AHS) } \\
\text { umfasst eine vierjährige } \\
\text { Unterstufe und eine } \\
\text { vierjährige Oberstufe } \\
\text { und schließt mit der } \\
\text { Reifeprüfung (Matura) ab.” }\end{array}$ & $\begin{array}{l}\text { Definíció: } \\
\text { Magyarországon létezik } 8 \\
\text { osztályos gimnázium. } \\
\text { A } 8 \text { osztályos gimnázium } \\
\text { az általános iskola negyedik } \\
\text { osztályának befejezését } \\
\text { követően kezdhető meg, így } \\
\text { a tanuló az általános iskola } \\
\text { felső tagozatát már } \\
\text { a gimnáziumban végzi el. }\end{array}$ & $\begin{array}{l}\text { Fogalmi összehasonlítás } \\
\text { eredménye / fogalmi különbség } \\
\text { leírása: } \\
\text { A két intézménytípus } \\
\text { megfeleltethető egymással. } \\
\text { Az osztrák iskolarendszerben } \\
\text { a } 8 \text { osztályos gimnázium } \\
\text { megnevezése, amely egy } \\
4 \text { osztályos alsó és egy } 4 \\
\text { osztályos felső tagozatból áll, és } \\
\text { érettségivel zárul, a különbség } \\
\text { azonban az AHS esetében, hogy } \\
\text { nem kötelező végigjárni, az első } \\
4 \text { osztály után el lehet menni } \\
\text { egy szakközépiskolába vagy } \\
\text { szakmunkásképzőbe. }\end{array}$ \\
\hline \multicolumn{3}{|c|}{ Az ekvivalencia szintje: teljes } \\
\hline \multicolumn{3}{|c|}{$\begin{array}{l}\text { Magyarázat: } \\
\text { Általános képzést nyújtó középiskola, amely érettségivel zárul. Az alsó tagozat } \\
\text { (Unterstufe) } 10 \text { és } 14 \text { éves kor között, míg a felső tagozat (Oberstufe) } 15 \text { és } 18 \text { év között } \\
\text { biztosítja az oktatást. Három különböző fajtája van: } \\
\quad \text { - általános gimnázium (Bundesgymnasium = BG), } \\
\quad \text { - reálgimnázium (Bundesrealgymnasium = BRG), } \\
\quad \text { - közgazdasági gimnázium (Wirtschaftskundlichen Realgymnasien = WKG). } \\
\text { AHS-be az ment, akinek továbbtanulási céljai voltak. Az érettséginek magas presztízse } \\
\text { van (,,az érettségizett ember valaki”) Ausztriában. Az AHS érettségije feljogosít arra az } \\
\text { egyetemi továbbtanulásra. }\end{array}$} \\
\hline \multicolumn{3}{|c|}{$\begin{array}{l}\text { Források: } \\
\text { https://www.oesterreich.gv.at/themen/bildung_und_neue_medien/schule/2/Seite.1760160. } \\
\text { html } \\
\text { https://www.bildungssystem.at/schule-unterstufe/allgemein-bildende-hoehere-schule- } \\
\text { unterstufe }\end{array}$} \\
\hline
\end{tabular}




\begin{tabular}{|c|c|c|}
\hline $\begin{array}{l}\text { 4. Terminus AT: } \\
\text { Berufsbildende Höhere } \\
\text { Schulen (BHS) }\end{array}$ & $\begin{array}{l}\text { Terminus HU: } \\
\text { szakközépiskola }\end{array}$ & $\begin{array}{l}\text { Ekvivalens: } \\
\text { Magasabb szakmai képzést } \\
\text { adó iskola/szakközépiskola }\end{array}$ \\
\hline $\begin{array}{l}\text { Definition: } \\
\text { „Berufsbildende höhere } \\
\text { Schulen vermitteln in fünf } \\
\text { Jahren neben einer fundierten } \\
\text { Allgemeinbildung eine } \\
\text { höhere berufliche Ausbildung } \\
\text { und schließen mit einer } \\
\text { Reife- und Diplomprüfung } \\
\text { ab.” }\end{array}$ & $\begin{array}{l}\text { Definíció: } \\
\text { Érettségit adó, szakmai } \\
\text { képzést nyújtó középiskola. }\end{array}$ & $\begin{array}{l}\text { Fogalmi összehasonlítás } \\
\text { eredménye / fogalmi } \\
\text { különbség leírása: } \\
\text { A két intézménytípus } \\
\text { megfeleltethető egymással. } \\
\text { Az osztrák iskolarendszerben } \\
\text { az } 5 \text { éves, szakmát } \\
\text { és érettségit adó } \\
\text { szakközépiskolák } \\
\text { megnevezése. }\end{array}$ \\
\hline \multicolumn{3}{|c|}{ Az ekvivalencia szintje: részleges } \\
\hline \multicolumn{3}{|c|}{$\begin{array}{l}\text { Magyarázat: } \\
\text { Olyan önálló szakközépiskola Ausztriában, amelyben az egységesen öt évig tartó } \\
\text { szakképzés mellett az általános müveltséget igazoló érettségit is megkapják a diákok. }\end{array}$} \\
\hline \multicolumn{3}{|c|}{$\begin{array}{l}\text { Források: } \\
\text { https://www.bildungssystem.at/schule-oberstufe/berufsbildende-hoehere-schule }\end{array}$} \\
\hline
\end{tabular}

\begin{tabular}{|c|c|c|}
\hline $\begin{array}{l}\text { 5. Terminus AT: } \\
\text { Schularbeit }\end{array}$ & $\begin{array}{l}\text { Terminus HU: } \\
\text { írásbeli dolgozat }\end{array}$ & $\begin{array}{c}\text { Ekvivalens: } \\
\text { írásbeli dolgozat }\end{array}$ \\
\hline $\begin{array}{l}\text { Definition: } \\
\text { „Schularbeiten sind im } \\
\text { Lehrplan vorgesehene } \\
\text { schriftliche Arbeiten } \\
\text { zum Zwecke der } \\
\text { Leistungsfeststellung } \\
\text { in der Dauer von einer } \\
\text { Unterrichtsstunde (in } \\
\text { Volkschule), sofern im } \\
\text { Lehrplan nicht anderes } \\
\text { bestimmt ist.” }\end{array}$ & $\begin{array}{l}\text { Definíció: } \\
\text { Magyarországon a } \\
\text { témazáró dolgozat áll a } \\
\text { Schularbeit terminushoz } \\
\text { a legközelebb, de annak } \\
\text { a hazai iskolarendszerben } \\
\text { nincs akkora jelentősége és } \\
\text { súlya, mint Ausztriában a } \\
\text { Schularbeitoknak. }\end{array}$ & $\begin{array}{l}\text { Fogalmi összehasonlítás } \\
\text { eredménye / fogalmi } \\
\text { különbség leírása: } \\
\text { A két fogalom nem } \\
\text { feleltethető meg egymással, } \\
\text { Magyarországon nincs a } \\
\text { Schularbeit terminusnak } \\
\text { megfeleltethető fogalom. } \\
\text { A Schularbeit olyan a } \\
\text { tantervben elöírt írásbeli } \\
\text { dolgozat az osztrák } \\
\text { iskolákban, amelyet előre } \\
\text { bejelentett időpontokban } \\
\text { írnak meg a gyerekek } \\
\text { teljesítményértékelés céljából. } \\
\text { Ez olyan írásbeli, amelyet } \\
\text { kötelező megírni, és ha } \\
\text { valamilyen oknál fogva ez } \\
\text { nem sikerült, akkor pótolni } \\
\text { kell. Ha nem írja meg diák } \\
\text { a kötelezően meghatározott } \\
\text { számú Schularbeitokat a } \\
\text { tantervben elöírtak szerint, } \\
\text { akkor akár évet is ismételhet. }\end{array}$ \\
\hline
\end{tabular}




\section{Az ekvivalencia szintje: részleges}

\section{Magyarázat:}

A dolgozatok megírásának idejét a szaktanár az igazgatóval közösen állapítja meg (1. félévben, legkésőbb négy héten belül, a 2. félévben legkésőbb két héttel az adott félév kezdete után), és később is csak az igazgató beleegyezésével változtathatja meg. A dolgozatok időpontját tantárgyanként kell megadni. Naponta csak egy írásbeli dolgozatot írhat a diák, a heti darabszám (1 vagy 3 ) az iskola típusától függően változhat. A népiskolák 4. osztályában ezeknek a dolgozatoknak az eredményétől függ a továbbtanulás. A tanár állítja össze a kérdéseket.

\section{Források:}

https://www.jusline.at/gesetz/lbv/paragraf/7

https://www.das.at/Rund-ums-Recht/Rechtstipps/Schulrecht

\begin{tabular}{|c|c|c|}
\hline $\begin{array}{l}\text { 6. Terminus AT: } \\
\text { Pflichtgegenstand }\end{array}$ & $\begin{array}{l}\text { Terminus HU: } \\
\text { kötelező tantárgy }\end{array}$ & $\begin{array}{c}\text { Ekvivalens: } \\
\text { kötelező tantárgy }\end{array}$ \\
\hline $\begin{array}{l}\text { Definition: } \\
\text { Pflichtfach in der Schule in } \\
\text { Österreich. }\end{array}$ & $\begin{array}{l}\text { Definíció: } \\
\text { Magyarországon is a } \\
\text { tantervben meghatározott, } \\
\text { kötelezően teljesítendő } \\
\text { tantárgyakat jelenti. }\end{array}$ & $\begin{array}{l}\text { Fogalmi összehasonlítás } \\
\text { eredménye / fogalmi különbség } \\
\text { leírása: } \\
\text { A két fogalom megfeleltethető } \\
\text { egymással. } \\
\text { A tantervben elöírt, kötelezően } \\
\text { oktatandó tantárgy az osztrák } \\
\text { iskolákban. }\end{array}$ \\
\hline \multicolumn{3}{|c|}{ Az ekvivalencia szintje: majdnem teljes } \\
\hline \multicolumn{3}{|c|}{$\begin{array}{l}\text { Magyarázat: Például egy reálgimnázium 11. osztályában kötelező tantárgyak: etika, } \\
\text { német, latin, angol, történelem, szociális ismeretek és politikai képzés, földrajz és gazdasági } \\
\text { ismeretek, kémia, fizika. }\end{array}$} \\
\hline \multicolumn{3}{|c|}{$\begin{array}{l}\text { Források: } \\
\text { https://www.jusline.at/gesetz/schug/paragraf/11\# } \\
\text { https://www.duden.de/rechtschreibung/Pflichtgegenstand }\end{array}$} \\
\hline
\end{tabular}




\begin{tabular}{|c|c|c|}
\hline $\begin{array}{c}\text { 7. Terminus AT: } \\
\text { Wahlplichtgegenstände } \\
\text { (WPG) }\end{array}$ & $\begin{array}{l}\text { Terminus HU: } \\
\text { fakultáció }\end{array}$ & $\begin{array}{c}\text { Ekvivalens: } \\
\text { kötelezően választandó tantárgy }\end{array}$ \\
\hline $\begin{array}{l}\text { Definition: } \\
\text { In der 6., 7. und } 8 . \\
\text { Klasse der AHS } \\
\text { haben die Schüler die } \\
\text { Möglichkeit, in Form von } \\
\text { Wahlpflichtgegenständen } \\
\text { (WPG) in einem } \\
\text { bestimmten Ausmaß } \\
\text { Bildungsschwerpunkte } \\
\text { zu setzen, die ihren } \\
\text { Interessen und } \\
\text { Fähigkeiten entsprechen. } \\
\text { Am Gymnasium } \\
\text { sind insgesamt } 8 \\
\text { Wochenstunden zu wählen. } \\
\text { Die WPG werden in zwei } \\
\text { Gruppen unterteilt: in die } \\
\text { Gruppe der zusätzlichen } \\
\text { WPG (das sind solche, } \\
\text { die im Stundenkanon } \\
\text { der Pflichtfächer nicht } \\
\text { enthalten sind) und } \\
\text { in die Gruppe der } \\
\text { vertiefenden WPG (diese } \\
\text { Fächer wurden bereits } \\
\text { im regulären Unterricht } \\
\text { abgedeckt und sind nicht } \\
\text { mehr gänzlich neu). }\end{array}$ & $\begin{array}{l}\text { Definíció: } \\
\text { Magyarországon } \\
\text { leginkább a fakultációnak } \\
\text { megfeleltethető tantárgy. } \\
\text { Fakultáció esetében } \\
\text { a diák hazánkban a } \\
\text { kötelező tantárgyak közül } \\
\text { választhatja ki a 10. } \\
\text { osztály végére azt az 1-2 } \\
\text { tárgyat, amelyet szeretne } \\
\text { magasabb szinten tanulni } \\
\text { annak érdekében, hogy } \\
\text { felkészüljön az emelt } \\
\text { szintű érettségire. }\end{array}$ & $\begin{array}{l}\text { Fogalmi összehasonlítás } \\
\text { eredménye / fogalmi különbség } \\
\text { leírása: } \\
\text { A két fogalom csak részlegesen } \\
\text { feleltethetö meg egymással, } \\
\text { azzal a különbséggel, hogy } \\
\text { Magyarországon a kötelező } \\
\text { tantárgyak közül választhatja ki } \\
\text { a diák 10. osztály végére azt az } \\
1 \text {-2 tárgyat, amelyet szeretne } \\
\text { magasabb szinten tanulni annak } \\
\text { érdekében, hogy felkészüljön az } \\
\text { emelt szintü érettségire. } \\
\text { Olyan tantárgycsoportot jelöl a } \\
\text { fogalom az osztrák iskolákban, } \\
\text { amelyböl kötelező választani, } \\
\text { amelyre külön jelentkezni kell, } \\
\text { és jegykötelezettséggel jár. } \\
\text { Nagyon széles és érdekes a } \\
\text { választható tárgyak köre. Számít } \\
\text { az adott tanév sikeres teljesítése } \\
\text { szempontjából. }\end{array}$ \\
\hline \multicolumn{3}{|c|}{ Az ekvivalencia szintje: részleges } \\
\hline \multicolumn{3}{|c|}{$\begin{array}{l}\text { Magyarázat: Például: programozás, kutatás a szabadban, mikrobiológia, maratontréning, } \\
\text { színház, zene improvizáció-dráma. }\end{array}$} \\
\hline \multicolumn{3}{|c|}{$\begin{array}{l}\text { Források: } \\
\text { https://www.jusline.at/gesetz/schug/paragraf/11\# } \\
\text { http://schulen.eduhi.at/gymschlierbach/verwaltung/wahlpflicht.htm } \\
\text { https://www.gymnasiumort.at/service/wahlpflichtgegenstaende } \\
\text { https://www.duden.de/rechtschreibung/Pflichtgegenstand }\end{array}$} \\
\hline
\end{tabular}




\begin{tabular}{|c|c|c|}
\hline $\begin{array}{l}\text { 8. Terminus AT: } \\
\text { Verbindliche Übung (VÜ) }\end{array}$ & Terminus HU: - & $\begin{array}{c}\text { Ekvivalens: } \\
\text { kötelezö gyakorlat }\end{array}$ \\
\hline $\begin{array}{l}\text { Definition: } \\
\text { Die verbindliche Übung } \\
\text { (z.B. „Berufsorientierung”) } \\
\text { kann integriert in } \\
\text { den Unterricht der } \\
\text { Pflichtgegenstände geführt } \\
\text { werden. Schulautonom ist } \\
\text { es möglich, einen eigenen } \\
\text { Unterrichtsgegenstand } \\
\text { Berufsorientierung (schon ab } \\
\text { der 2. Klasse) zu führen. }\end{array}$ & $\begin{array}{l}\text { Definíció: } \\
\text { Magyarországon nincs } \\
\text { ennek megfeleltethető } \\
\text { fogalom. Hasonló tartalmú } \\
\text { és tematikájú foglalkozások, } \\
\text { előadások a hazai iskolákban } \\
\text { leginkább a projekthéten } \\
\text { fordulnak elö, de az nem } \\
\text { kerül be a bizonyítványba. }\end{array}$ & $\begin{array}{l}\text { Fogalmi összehasonlítás } \\
\text { eredménye / fogalmi } \\
\text { különbség leírása: } \\
\text { Olyan kötelezö gyakorlat az } \\
\text { osztrák iskolarendszerben, } \\
\text { amely integrálható a kötelező } \\
\text { tantárgyak oktatásába. } \\
\text { Az iskolák maguk } \\
\text { dönthetnek ezekről (2. } \\
\text { osztálytól kezdve egészen az } \\
\text { érettségiig). }\end{array}$ \\
\hline \multicolumn{3}{|c|}{ Az ekvivalencia szintje: ekvivalencia hiánya } \\
\hline \multicolumn{3}{|c|}{$\begin{array}{l}\text { Magyarázat: A bizonyítványában is megjelenik, hogy ezen a gyakorlaton jelen volt } \\
\text { (teljesítette). Ilyen kötelező gyakorlat például a közlekedési ismeretek, amelyet a } \\
\text { környezetóra keretében tanulnak meg a gyerekek. Ilyenkor kinn az úttesten gyakorolnak, } \\
\text { ahol egy rendőr oktatja őket. Hasonló kötelező gyakorlatként szerepel a tanrendben például } \\
\text { a biciklisvizsga, amelyet } 10 \text { évesen tesznek le a gyerekek. Ha ezt a vizsgát leteszik, akkor } \\
\text { mehetnek csak egyedül biciklivel az utcán. }\end{array}$} \\
\hline \multicolumn{3}{|c|}{$\begin{array}{l}\text { Források: } \\
\text { https://www.oepu.at/oepualt/index.php/service/rechts-infos/infos-a-z/830-unverbueb }\end{array}$} \\
\hline
\end{tabular}

\begin{tabular}{|l|l|l|}
\hline \multicolumn{1}{|c|}{ 9. Terminus AT: } & \multicolumn{1}{|c|}{ Terminus HU: - } & \multicolumn{1}{c|}{$\begin{array}{c}\text { Ekvivalens: } \\
\text { szabadon választható } \\
\text { tantárgy }\end{array}$} \\
\hline $\begin{array}{l}\text { Definition: } \\
\text { „Unter Freigegenständen sind } \\
\text { jene Unterrichtsgegenstände } \\
\text { zu verstehen, zu deren Besuch } \\
\text { ebenfalls eine Anmeldung } \\
\text { für jedes Unterrichtsjahr } \\
\text { erforderlich ist (die also } \\
\text { ebenfalls fakultativ sind und } \\
\text { freiwillig ,,gebucht” werden), } \\
\text { die aber beurteilt werden (mit } \\
\text { Noten gemäß Notenskala).” }\end{array}$ & $\begin{array}{l}\text { Definíció: } \\
\text { megfeleltethető fogalom. }\end{array}$ & $\begin{array}{l}\text { Fogalmi összehasonlítás } \\
\text { eredménye / fogalmi kü- } \\
\text { lönbség leírása: } \\
\text { Olyan szabadon választható } \\
\text { tantárgy az osztrák iskolák- } \\
\text { ban, amelyre minden tanév- } \\
\text { ben külön jelentkezni kell, és } \\
\text { amelyet jeggyel értékelnek } \\
\text { (az osztályozási skála szerin- } \\
\text { ti osztályzatokkal). } \\
\text { Az értékelés nincs hatással } \\
\text { az adott tanév sikeres tel- } \\
\text { jesítésére, azaz nem lehet } \\
\text { miatta megbukni. }\end{array}$ \\
\hline \begin{tabular}{l} 
Az ekvivalencia szintje: részleges \\
\hline
\end{tabular} & \\
\hline
\end{tabular}


Magyarázat: A szabadon választható tantárgyak csoportja minden iskolában más és más, nagyon széles lehet a választék a különböző iskolai szinteken is. A gyakorlati csoportok 15 diákkal, idegen nyelvek esetében 12 diákkal indulhatnak el. A kisebbségi nyelvek (bosnyák/ horvát/szerb, szlovén és magyar nyelv) választásakor a törvény megengedőbb, 8 tanuló jelentkezése szükséges a kurzus elindításához, kilencedik osztálytól pedig 5 tanuló. Ha a tanulók száma nem éri el az osztályban a szükséges minimális tanulólétszámot, egy vagy több iskola több osztályának tanulói is kombinálhatók a minimális létszám elérése érdekében (SchOG 8a/1). Ebben a formában tanulható tárgyak például: Bevezetés a tudományos munkába, etika, gépírás, informatika stb.

\section{Források:}

https://www.oepu.at/oepualt/index.php/service/rechts-infos/infos-a-z/830-unverbueb https://www.ptsgg.at/index.php/home/unverbindliche-uebungen-und-freigegenstaende.html https://www.jusline.at/gesetz/schug/paragraf/12

\begin{tabular}{|c|c|c|}
\hline $\begin{array}{c}\text { 10. Terminus AT: } \\
\text { Unverbindliche Übung } \\
\text { (UÜ) }\end{array}$ & Terminus HU: - & \begin{tabular}{|c|} 
Ekvivalens: \\
szabadon választható gyakorlat \\
(tükörfordítása: nem kötelező \\
érvényű gyakorlat)
\end{tabular} \\
\hline $\begin{array}{l}\text { Definition: } \\
\text { Unter, „unverbindlichen } \\
\text { Übungen” sind (gemäß } \\
\text { SchOG } 8 \text { lit. i) jene } \\
\text { Unterrichtsveranstaltungen } \\
\text { zu verstehen, zu deren } \\
\text { Besuch eine Anmeldung } \\
\text { für jedes Unterrichtsjahr } \\
\text { erforderlich ist und die } \\
\text { nicht beurteilt werden. Das } \\
\text { heißt, dass unverbindliche } \\
\text { Übungen im Zeugnis nur } \\
\text { einen Teilnahmevermerk } \\
\text { erhalten und weder für } \\
\text { die Feststellung des } \\
\text { ausgezeichneten oder guten } \\
\text { Erfolges noch für den } \\
\text { erfolgreichen Abschluss } \\
\text { einer Schulstufe relevant } \\
\text { sind. }\end{array}$ & $\begin{array}{l}\text { Definíció: } \\
\text { Magyarországon nincs ennek } \\
\text { megfeleltethető fogalom. } \\
\text { Olyan, mintha a szakköröket } \\
\text { beépítenénk a tanrendbe. }\end{array}$ & $\begin{array}{l}\text { Fogalmi összehasonlítás } \\
\text { eredménye / fogalmi } \\
\text { különbség leírása: } \\
\text { A jegykötelezettséggel nem } \\
\text { járó szabadon választott } \\
\text { tantárgyakat értjük alatta, } \\
\text { amelyekre minden tanévben } \\
\text { külön jelentkezni kell. } \\
\text { A bizonyítványban csak } \\
\text { a részvételt igazolják: } \\
\text { Teilgenommen / részt vett. } \\
\text { Jegykötelezettséggel nem } \\
\text { jár, és nem számít az adott } \\
\text { tanév sikeres teljesítése } \\
\text { szempontjából sem, azaz nem } \\
\text { lehet miatta évet ismételtetni. }\end{array}$ \\
\hline \multicolumn{3}{|c|}{ Az ekvivalencia szintje: részleges } \\
\hline \multicolumn{3}{|c|}{$\begin{array}{l}\text { Magyarázat: A gyakorlati csoportok } 15 \text { diákkal, idegen nyelvek esetében } 12 \text { diákkal indulhatnak } \\
\text { el. A kisebbségi nyelvek (bosnyák/horvát/szerb, szlovén és magyar nyelv) választásakor a törvény } \\
\text { megengedőbb, legalább } 8 \text { tanuló jelentkezése szükséges a kurzus elindításához, kilencedik } \\
\text { osztálytól pedig legalább } 5 \text { tanuló. Ha a tanulók száma nem éri el az osztályban a szükséges } \\
\text { minimális tanulólétszámot, egy vagy több iskola több osztályának tanulói is kombinálhatók } \\
\text { a minimális létszám elérése érdekében (SchOG } 8 \mathrm{a} / 1 \text { ). Ebben a formában választható tárgyak } 11 \text {. } \\
\text { osztályban például: kórus, zenekar, színjátszás, kézilabda, magyar nyelv stb. }\end{array}$} \\
\hline \multicolumn{3}{|c|}{$\begin{array}{l}\text { Források: } \\
\text { https://www.oepu.at/oepualt/index.php/service/rechts-infos/infos-a-z/830-unverbueb }\end{array}$} \\
\hline
\end{tabular}




\section{6. Összegzés}

Tíz oktatási terminust választottam ki a Termini magyar-magyar szótárból, és ezek terminológiai elemzését készítettem el. A tanulmány megírásával célom többszörös volt: (1) szerettem volna felhívni a figyelmet a Termini Magyar Nyelvi Kutatóhálózat 2021-ben már két évtizede folyamatosan zajló határtalanító tevékenységére, (2) a Kutatóhálózat által szinte kezdetektől épített és bővített Termini magyar-magyar szótár hasznosíthatóságára, (3) a szótárban rejlő további azon lehetöségekre, amelyek többek között azon alapulnak, hogy a szótár egyszerre nyolc ország magyar közösségének a mindennapokban használt államnyelvi kontaktuselemeit, az anyaországhoz képest már marginalizálódott szavait és önálló szóalkotásait tartalmazza. Így a szótár alkalmas a több szempontú összehasonlításra és elemzésre. (4) Céljaim között szerepelt az is, hogy rámutassak, nemcsak a magyar közösségek nyelvi szétfejlődésének voltunk tanúi a Kárpát-medencében, hasonlóan különfejlődtek a környezö országok oktatási rendszerei is. S bár látszólag hasonló a szerkezet, mégis különböző gyakorlatok alakultak ki a szomszédos országok mindegyikében.

Míg a rendszerváltás óta a digitalizációnak is köszönhetően nyelvi közeledésről beszélünk, addig az oktatási rendszerek közeledése nem egyértelmü. A magyarországi oktatáspolitika folyamatosan tesz lépéseket annak érdekében, hogy a környező országok magyar pedagógusai, oktatási szakemberei megismerjék és nyomon tudják követni a hazai közoktatás változásait (továbbképzések, konferenciák, eszmecserék stb.), és a magyarországi oktatáskutatók, közszolgák is törekednek a környező országok oktatási rendszerének megismerésére, ez tulajdonképpen nemzetpolitikailag fontos.

Összefoglalásként elmondhatjuk, hogy az oktatási rendszerek különfejlődése ahogy ez a tíz terminus bemutatásával láthatóvá vált - számos problémára felhívja a figyelmet, ezek egyike csupán az a hátrány, amelynek a tanuló ki van téve, ha egyik országból a másikba költözik. Ezt a hátrányt fokozza, ha a szülőnek nincs megfelelő ismerete az adott ország közoktatásáról, és ha nincs megfelelő nyelvi kompetenciája ahhoz, hogy az információ megszerzéséért interakcióba lépjen. Mivel a migráció nyugati irányú, célországa a környező országok közül Ausztria, így az ottani oktatáspolitika és az iskolai előmenetel lehetőségeinek megismerése a migrációs mozgások alkalmával létfontosságú, az oktatási terminológiai különbségek feltárása pedig szociolingvisztikai szempontból hasznos nyelvészet.

\section{SZAKIRODALOM}

Arntz, Reiner - Picht, Heribert - Mayer, Felix 2009. Einführung in die Terminologiearbeit. Hildesheim, Georg Olms Verlag, Zürich-New York (6. Aufl.).

Benő Attila-Péntek János szerk. 2011. A Termini Magyar Nyelvi Kutatóhálózat 10 éve. Gramma-SZTANYI, Dunaszerdahely-Kolozsvár.

Fóris Ágota - Bölcskei Andrea (szerk.) 2019. Terminológiastratégiai kihívások a magyar nyelvterületen. L'Harmattan Kiadó-OFFI Zrt., Budapest.

Karcsay Sándor 1978. Szakszöveg - szakfordítás. Tudományos és müszaki tájékoztatás 25: $515-22$. 
Langerné Buchwald Judit 2017. Ingázó diákok avagy tanulási célú ingázás az osztrák-magyar határ mentén. Fakultás Kiadó, Budapest.

Szoták Szilvia 2017a. Gondolatok nyelv és gazdaság viszonyáról. In: Gróf Annamária Kolláth Anna - Szoták Szilvia (szerk.): Szélrózsa. Termini Egyesület, Budapest, 72-83.

Szoták Szilvia 2017b. A Termini magyar-magyar szótár burgenlandi gyakorlati példái. In: Fábián Zsuzsanna (szerk.): Szótárírás a Kárpát-medencében. A magyar és a szomszédos országok többségi nyelveinek kétnyelvü szótárai. Lexikográfiai füzetek 8. Budapest, $228-41$.

Tamás Dóra Mária 2019. Bevezetés a jogi terminológiába a terminológus szemüvegén át. OFFI Zrt., Budapest.

Tolcsvai Nagy Gábor 2013. A határtalanítás az Osiris idegen szavak szótárában és a szókészlet. Magyar Nyelv 137: 379-8.

Tolcsvai Nagy Gábor 2017. Bevezetés. In: Tolcsvai Nagy Gábor (szerk.): A magyar nyelv jelene és jövője. Gondolat Kiadó, Budapest, 19-31.

\author{
Szoták Szilvia \\ elnök \\ Imre Samu Nyelvi Intézet \\ Termini Magyar Nyelvi Kutatóhálózat \\ https://orcid.org/0000-0003-3218-9525
}

\title{
SUMMARY
}

Szoták, Szilvia

\section{A terminological and sociolinguistic analysis of country-specific educational terms based on examples from the Termini Hungarian-Hungarian dictionary (Austria)}

In this study, I analyse terminological and sociological aspects of ten educational terms found in the Termini Hungarian-Hungarian dictionary. By writing this study I intend to draw attention (1) to the border-crossing activities of the Termini Hungarian Language Research Network, having been pursued for two decades, (2) the usefulness of the Termini Hungarian-Hungarian dictionary, built and expanded by the Research Network almost from the beginning, and (3) the further potential of the dictionary. The dictionary contains everyday contact elements of the Hungarian communities of eight countries, as well as the words and independent word-forms of the Hungarian community of the motherland, which have been marginalised in relation to the Hungarian community. The dictionary thus lends itself to multi-perspective comparison and analysis. (4) My aim is also to show that we have not only witnessed the linguistic disintegration of Hungarian communities in the Carpathian Basin, but also that of the educational systems of the surrounding countries. And although apparently similar in structure, different practices have developed in each of the neighbouring countries.

The different development of education systems, as illustrated by the presentation of the ten terms under scrutiny, highlights a number of problems, one of which is simply the disadvantage a pupil is exposed to when moving from one country to another. This disadvantage is compounded if the parents do not have sufficient knowledge of the public education in the country concerned and lack the linguistic competence to interact to obtain information. 
As migration is westward, with Austria being the destination country among the neighbouring countries, learning about the educational policies and opportunities for school progression in Austria is vital for migratory movements, and exploring differences in educational terminology is a useful linguistic-sociolinguistic exercise.

Keywords: educational terms, Termini Hungarian-Hungarian dictionary, Termini Hungarian Language Research Network, education systems

\section{Ízelítők a Termini magyar-magyar szótár kárpátaljai anyagából}

\section{Bevezetés}

Húsz évvel ezelőtt, 2001-ben jött létre a Magyarországgal szomszédos államokban müködő magyar nyelvészeti kutatóhelyek hálózata, a Termini Kutatóhálózat (Péntek 2009). ${ }^{7}$ 2011-ben, a kutatóhálózat fennállásának első kerek, tizedik évfordulóján reprezentatív kötetben mutattuk be, kik vagyunk, mivel foglalkozunk (Benő-Péntek szerk. 2011). Amint a Magyar Nyelvőr jelen számában fentebb közölt tanulmányokból is kiderül, a közös kutatási programok egyike a Magyarországon kívül beszélt és írott magyar nyelvváltozatok sajátos szókészleti elemeinek gyűjtése, rendszerezése, elemzése. A 2007 óta online is elérhető szótárunkba ${ }^{8}$ azokat a magyarországiaktól eltérö, idegen eredetü (az adott régió magyar nyelvhasználatában rendszerint az államnyelvből származó vagy kontaktushatásra visszavezethető) szavakat, szójelentéseket gyüjtjük össze, amelyeket a Kárpát-medencében, Magyarország határain túl élő őshonos magyar kisebbségi közösségekben használnak. A kizárólag valamely Magyarországgal szomszédos államban használt szavak, szókapcsolatok mellett azokat a lexémákat is gyüjtjük az adatbázisba, amelyek Magyarországon is használatosak, de más jelentésben (Lanstyák-Benő-Juhász 2011; Benő-Juhász-Lanstyák 2020).

Mivel ez az online szótári adatbázis a magyarral a Kárpát-medencében érintkező számos nyelvből (főként a Magyarországgal szomszédos országok államnyelveiből, többségi nyelveiből: szlovák, ukrán, orosz, román, szerb, horvát, szlovén, német) tartalmaz (föként) közvetlen kölcsönszókat, az adatbázis a magyar és az indoeurópai nyelvek közötti kontaktusok vizsgálatának gazdag forrása. Mivel nem papíralapú, hanem internetes szótári adatbázisról van szó, az egyes szócikkek szerkesztése során gyakorlatilag nincsenek terjedelmi korlátok, így a sok élőnyelvi példamondat, a bő kontextus lehetővé teszi a jelentésárnyalatok elkülönítését, a stílusminősítések pontosítását. A könnyen kereshető adatbázisban a címszavak számos szempont szerint listázhatók: régió, stílusminősítés, átadó nyelv, szófaj, fogalomkör stb.

7 http://termini.nytud.hu/

8 http://termini.nytud.hu/htonline/htlista.php?action=firstpage 